ECHOES OF SCRIPTURE IN THE LETTERS OF PAUL 
This page intentionally left blank 


\section{E CHOES O F}

\section{SCRIPTURE IN THE}

LETTERS OF

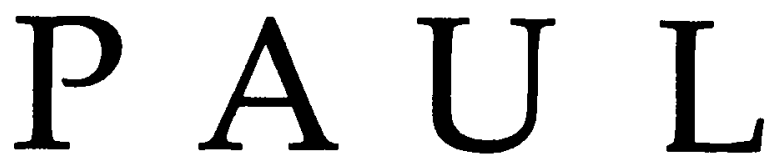

RICHARD B. HAYS

YALE UNIVERSITY PRESS NEW HAVEN \& LONDON 
Copyright 1989 by Richard B. Hays.

All rights reserved.

This book may not be reproduced, in whole or in part, including illustrations, in any form (beyond that copying permitted by Sections 107 and 108 of the U.S. Copyright

Law and except by reviewers for the public press), without written permission from the publishers.

Excerpt from "Ash Wednesday" in Collected Poems, 1909-1962 by T. S. Eliot, copyright 1936 by Harcourt Brace Jovanovich, Inc., copyright 01963,1964 by T. S. Eliot, reprinted by permission of the publisher. Permission to reprint outside the U.S. granted by Faber and Faber Limited, Publishers.

"The Nineteenth Century and After" reprinted with permission of Macmillan Publishing Company from The Poems of W. B. Yeats: A New Edition, edited by Richard J. Finneran. Copyright 1933 by Macmillan Publishing Company, renewed 1961 by Bertha Georgie Yeats. Permission to reprint outside the U.S. granted by A. P. Watt Ltd. on behalf of Michael B. Yeats and Macmillan London Ltd.

Designed by James J. Johnson

and set in Palatino Roman types by The Composing Room of Michigan, Inc. Printed in the United States of America.

Library of Congress Cataloging-in-Publication Data

Hays, Richard B.

Echoes of scripture in the letters of Paul / Richard B. Hays.

p. $\mathrm{cm}$.

Bibliography: p.

Includes index.

ISBN: 978-0-300-05429-3

1. Bible. N.T. Epistles of Paul-Relation to the Old Testament.

2. Bible. O.T.-Quotations in the New Testament. 3. Bible. N.T.

Epistles of Paul-Criticism, interpretation, etc. 1. Title.

$\mathrm{BS}_{2655} \mathrm{R}_{32 \mathrm{H}} 39 \quad 1989$

$227^{\prime} .066-\mathrm{dc} 19$

89-30110

CIP

A catalogue record for this book is available from the British Library.

The paper in this book meets the guidelines for permanence and durability of the Committee on Production Guidelines for Book Longevity of the Council on Library Resources. 
This book is dedicated to

\title{
George Hobson,
}

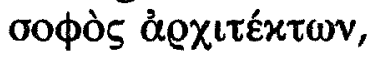

\author{
and to the memory of \\ John Harold Gibbs
}

(1940-1982),

whose life was a true reading of the gospel. 
This page intentionally left blank 